\title{
Reflections on Sticking to "Taking Undergraduate Education as the Foundation, Implementing Four Returns, Developing First-Rate Majors, and Constructing Topping Undergraduate Education" in Local University
}

\author{
-A Case Study Based on Guangdong Ocean University
}

\author{
Guangya Zhang \\ Educational Information Center \\ Guangdong Ocean University \\ Zhanjiang, China \\ zhangguangya@126.com
}

\author{
Lingli Fan* \\ School of ocean and meteorology \\ Guangdong Ocean University \\ Zhanjiang, China \\ *Corresponding author, fanlingli@126.com
}

\begin{abstract}
Guangdong Ocean University aims to cultivate high-quality professionals and elites with international vision and social responsibility, with autonomous learning ability, practical ability and innovative spirit. The university is fully implementing the spirit of Chinese President Xi Jinping's important speech on inspecting Guangdong, sticking to "taking undergraduate education as the foundation, implementing four returns, developing first-rate majors, and constructing topping undergraduate education" work ethic in the New Era, deepening the educational reform with a high sense of responsibility, and with a spirit of racing against time. Only by implementing the measures mentioned above can Guangdong Ocean University improve the quality of talents training, create a new situation of undergraduate education, and realize a sustainable and healthy development.
\end{abstract}

Keywords-undergraduate education; four returns; with marine characteristics; local university

\section{INTRODUCTION}

Socialism with Chinese characteristics has entered a new era, and Chinese education, especially higher education, has entered a new historical stage of development [Chen B, 2018]. 2018 is crucial for the development of Chinese education. On May 2nd, when visiting Peking University, Mr. Xi pointed out: "Good education leads to a powerful country. Higher education is an important symbol of the country's development level and potential. At present, the national demand for higher education, scientific knowledge and talents is more urgent than ever before [Xi J, 2018]." At the same time, Mr. Xi pointed out that, training socialist constructors and successors is the educational policy of Communist Party of China (CPC), which is the common mission of all kinds of schools in China. On June 21st, the Ministry of Education held a national conference on undergraduate education in Chengdu, which is the first one in the past 40 years since the reform and opening-up. The meeting made specific arrangements for in-depth study of Mr. Xi's socialist ideology with Chinese characteristics in the new era, full deployment of universities to implement the fundamental task of cultivating virtuous person, and construction of topping undergraduate education [Chen B, 2018]. On September 10th, when the National Education Congress was held, Mr. Xi emphasized that: "Education work should be under the strong leadership of the CPC, fully implement the education policy of the CPC, adhere to the guiding position of Marxism, stick to the socialist road with Chinese characteristics, persist the socialist orientation, root on the basic national conditions, follow the laws of education, and adhere to reform. Education aims to cultivate socialist constructs and successors with allround development of morality, intelligence, sports, beauty and labor. China is accelerating the modernization of education, constructing a powerful education in China [Jin $\mathrm{H}$ et al., 2018]. " During October 22-25, when China was celebrating the 40th anniversary of reform and opening, Mr. Xi once again inspected Guangdong, the pioneer place of reform. He put forward four requirements for Guangdong, namely, deepening reform and opening, promoting high-quality development, improving the balance and coordination of development, and strengthening CPC Leadership and Construction. Mr. Xi's special visit to Jinan University fully reflects the CPC (with Xi Jinping as its core) Central Committee's attention, concern and expectation for Guangdong's education [Liu et al., 2018], which is a great encouragement and spur for us.

In this context, it is of great practical significance for Guangdong Ocean university to think deeply about, how can fully implement the spirits of the National Education Congress, Mr. Xi's important speech on inspecting Guangdong and the National Conference on Undergraduate Education in the New Era. Guangdong Ocean university, a local university with professional characteristics, should stick to the principle of " taking undergraduate education as the foundation, 
implementing four returns, developing first-rate majors, and constructing topping undergraduate education" [Wan Y, 2018], and comprehensively improve the undergraduate teaching ability.

\section{THE NEW Mission OF UNDERGRAdUATE EDUCATION IN THE NEW ERA}

\section{A. The National Conference on Education has laid out a positive print and pointed out the direction for education in the new era}

Mr. Xi made an important speech at the first National Education Congress, made a comprehensive, systematic and indepth elaboration and deployment of education in the new era. From the perspective of the development of the CPC and China in the new era, he summarized the remarkable achievements of Chinese education, analyzed the new situation and tasks of education, and answered the important questions about Chinese education modernization. Major plans have been made for the education in the future, which point out the way forward for accelerating the modernization of education, building a powerful country in education, and running a satisfactory education for the people [Renmin Ribao,2018].

For education, what kind of talents to train is the primary issue. "To train socialist builders and successors with general development in the aspects of moral, intellectual, and physical education [Xi J, 2018]" is the fundamental task of education. But how to achieve this target? Mr. Xi put forward "six efforts" should be made to strengthen ideals and beliefs, patriotism, morality, knowledge, spirit of struggle and comprehensive quality [Jiao X, 2018]. At present, China is at the key point of transforming from a big country of higher education to a powerful one. Reform and opening up, socialist modernization, human development and social progress put forward new and higher requirements for education [Renmin Ribao, 2018]. We must break away from the traditional work routine; have a thorough understanding of the new situation, plan new ideas for development, and strategically plan for the comprehensive reform of education in Guangdong Ocean University.

\section{B. Mr. Xi raised new expectations for higher education when he inspected Guangdong}

On October 22-25, 2018, Xi Jinping inspected Guangdong, the pioneer place of reform and opening up, and visited Jinan University specially, which fully reflects the concern and expectation for Guangdong education from the Central Committee of the CPC with $\mathrm{Xi}$ Jinping as its core [Party Building,2018]. For us, this is a great encouragement and spur. As the only Ocean University in South China, Guangdong Ocean University should actively integrate into the construction of the China Great Bay Area, actively dock the marine industry chain, and contribute to building China into a marine economic powerful nation. We should do a good job in training students from the China Great Bay Area and overseas with a higher historical position, a broader international vision and a deeper strategic vision. To do a good job in the education and training of students from Hong Kong, Macao, Taiwan and overseas with a higher historical position and a broader international vision.

\section{In the new era, the National Conference on undergraduate education put forward new requirements for undergraduate education}

On June 21st, 2018, the First National Conference on undergraduate education pointed out that talent cultivation is the essential function of universities, and undergraduate education is the root and foundation of universities [Wan Y, 2018]. The higher education should set up the concept of "three disqualifications", that is, universities that do not attach importance to undergraduate education are not qualified universities, principals who do not attach importance to undergraduate education are not qualified principals, and professors who do not participate in undergraduate education are not qualified professors. Adhering to the principle of "taking undergraduate education as the foundation", put undergraduate education at the core of talents training. The conference emphasized "Eight First", that is, the attention of university leaders should first focus on undergraduate courses, teachers' energy should first focus on undergraduate courses, school resources should first be allocated in undergraduate courses, teaching conditions should first be used in undergraduate courses, teaching methods and incentive mechanisms should first be innovated in undergraduate courses, core competitiveness and teaching quality should first appear in undergraduate courses, development strategies and universityrunning concepts should first be in undergraduate courses, the core value system should first be established in the undergraduate course [Wan Y,2018].

The Education Secretary stressed that the "Four Returns" should be promoted, and the quality of talents training should be taken as the fundamental criterion to test all work. We should return to common sense, organize education around students' hard work, and guide students to seek truth, learn and practice their real skills. Teachers should be guided to love teaching, devote themselves to teaching, practice teaching and devote themselves to teaching and training students. We should return to the original intention, adhere to the correct political direction, and promote the combination of professional knowledge education and ideological and political education, use knowledge system, value system and innovation system education to do so, devote ourselves to training builders and successors. We should return to our dreams, promote the innovation of university-running concept, organization, and management. Make every effort to realize the dream of building China into a powerful education nation [Wan Y, 2018].

The spirit of this conference is essentially a reform from the heart of higher education, a reinforcing of the fundamental position of undergraduate education in universities, a positive response to the existing problems in the current undergraduate education, and an important way for universities to further promote the reform of education.

\section{BASIC CONDITIONS AND PROBLEMS OF UNDERGRADUATE EDUCATION IN GUANGDONG OCEAN UNIVERSITY}

Combining with the above judgments on the current educational situation, we must realize that the undergraduate talent training and teaching reform of Guangdong Ocean 
University have entered a critical stage. Compared with the requirements of first-class undergraduate construction, we are facing with deeper contradictions and problems, and need to overcome gaps and shortcomings.

\section{A. The quality of undergraduate education needs to be improved}

To promote the implementation of the spirit of the National Conference on undergraduate Education in Guangdong Ocean University, we should unify our ideals, find a breakthrough and grasp the key points. Under the strategy of "challenging firstclass, overcoming disadvantages, strengthening characteristics", as a local industry university, how to create advantages and highlight characteristics in the fierce competition is a problem we must always think about. In the process of compiling the overall plan for the high-level university construction, we analyzed that the rapid development of many top domestic ocean-related universities will pose new challenges to our traditional advantageous disciplines, and we no longer have the original advantages and resource reserves to participate in the fierce competition. Although great progress has been made in various undertakings in recent years, there are still some gaps in comparison with similar universities and with the construction objectives of us, such as management and operation system, cultivation of outstanding innovative talents, international cooperation mechanism, construction of key platforms, and so on. Only with new ideals and advanced strategy, Guangdong Ocean University can achieve leapfrog sustainable development in the new era.

\section{B. The university' orientation and the goal of talents training are not sufficiently adapted to the needs of national and regional development}

First, the professional characteristics are not distinct. At present, the problems of imbalance between various major developments, unclear professional characteristics are still prominent. Secondly, the fit between talent training objectives and social needs should to be further integrated. Some majors are not aware of the rapid development of the tracking industries, ignoring the needs of regional economic development, which leads to the lag of talent training behind social needs. Thirdly, the teaching reform is not systematic, the teaching mode is bald, the teaching content is obsolete, the classroom teaching is rigid, the practice teaching is weak, the high-level teaching achievement is lacking, and the international exchange is lagged. Fourth, teaching management and talent training do not match very well. It is imperative to adjust and rebuild the new talent training system, training mode, teaching methods and teaching management system.

\section{Teachers and teaching resources are insufficiently guaranteed}

In terms of teachers, the first problem is that the insufficient teachers, and the high faculty-to-student ratio. The second is structural imbalance. Third, the renewal of teaching concept lags behind social needs. Fourth, teaching level needs to be improved. Fifth, the conversion from academic advantage to teaching advantage is not enough. In terms of resources, funds are insufficient, teaching administrative rooms are not up to the standard, laboratories, libraries and other hardware and software construction should be strengthened. On the one hand, the number of experiments and instruments is insufficient, on the other hand, equipment has not been fully utilized, that is, the sharing of resources is insufficient. The application of "Internet + " in teaching is still in its infancy.

\section{Teachers and teaching resources are insufficiently guaranteed}

In terms of teachers, the first problem is that the insufficient teachers, and the high faculty-to-student ratio. The second is structural imbalance. Third, the renewal of teaching concept lags behind social needs. Fourth, teaching level needs to be improved. Fifth, the conversion from academic advantage to teaching advantage is not enough. In terms of resources, funds are insufficient, teaching administrative rooms are not up to the standard, laboratories, libraries and other hardware and software construction should be strengthened. On the one hand, the number of experiments and instruments is insufficient, on the other hand, equipment has not been fully utilized, that is, the sharing of resources is insufficient. The application of "Internet +" in teaching is still in its infancy.

\section{E. The effectiveness of the teaching and quality assurance system is insufficient}

First, the university's teaching guarantee and service system is not perfect. Second, the scientific, normative and executive power of teaching management needs to be further strengthened. Especially, the corresponding measures with the two-level management of colleges and the whole university need to be improved.

\section{F. Students' satisfaction with teaching is not high}

The concept of student-centered and ability-oriented has not been fully integrated into the whole process of teaching and management.

\section{G. The effect of teaching reform is not obvious}

Regardless of the subject evaluation indicators of the State Council or the various ranking indicators of universities, the scores of national-level teaching achievement awards, nationallevel courses (including online open courses recognized by China), national-level students' competition awards, and students' international exchanges are significantly lower than the national average.

Some of these problems are new ones in the process of development, and some are difficult problems accumulated over long time. Solving these problems is the key to seize the opportunities in the fierce competition, improve the quality of education, highlight the characteristics, and gain a favorable position for further development. It is also the key to fully implement the spirits of Mr. Xi's important speech on inspecting Guangdong, the National Conference on education and the National Conference on undergraduate education in our university. 
IV. NEW MEASURES FOR GUANGDONG OCEAN UNIVERSITY TO BUILD FIRST-CLASS UNDERGRADUATE EDUCATION IN THE NEW ERA

The road of university starts from "talent cultivation" and "talent cultivation" starts from undergraduate education. The Minister of education, Chen Baosheng pointed out that, "The undergraduate course is the foundation of the great plan of higher education [1]." Only by truly integrating curriculums, teachers, teaching, students, teaching methods and technology on the major platform, building solid majors and running firstclass undergraduate courses well, can the goal of training firstclass talents be realized [Wu Y,2017]. To this end, we should make every effort to, uphold the principle of "based on undergraduate education", implement the four returns, improve the quality of training, and create a first-class undergraduate education with student-centered in Guangdong Ocean University.

\section{A. Implementing the fundamental task of moral education}

Undergraduate education is an important stage for students to mature, and also a critical period for students to form their world outlook, outlook on life and values. It is the fundamental task of universities to train socialist builders and successors with all-round development of morality, intelligence, physical fitness, beauty and labor.

We should take the effectiveness of moral education as the basic standard to test all the work of universities [Liu W, 2018], integrate the education of socialist core values into the whole process of teaching, and help students correctly understand the laws of history, accurately grasp the basic national conditions, and grasp the scientific world outlook and methodology. We should guide students to develop good moral character and behavior habits, cultivate high-quality professionals and industry elites with international vision and social responsibility, autonomous learning ability, practical ability and innovative spirit.

\section{B. Consolidating the basic position of undergraduate education}

Establishing the idea that talent training is the core mission of the university. "Leadership, teachers, resource allocation, funding arrangement and job evaluation [11]" should fully embody the concept of talent training-centered. It is necessary to establish the idea that the quality of training is the university' lifeline. Promoting students' all-round development and adapting to social needs are the basic standards of graduate quality. Students should not only be trained to become talents, but also be able to adapt to and control the future.

\section{Building first-class corps of teachers}

Teachers are the strategic resources of university, and the topping teaching staff is the key factor to build a first-class undergraduate course.

1) To speed up the solution of insufficient teachers

By the end of the 13th Five-Year Plan, Guangdong Ocean University will strive to have 1600 full-time teachers, with a student-teacher ratio around 18:1.

\section{2) To strengthen the construction of teaching management} team

Strengthen the construction of teaching management team, fully equipped with full-time teaching management stuff, to ensure that educational administration is carried out in a standardized and orderly manner.

\section{3) To veto the teacher just for his bad morality}

Strictly implement the one-vote veto system for teaching, in the promotion of teachers' technical titles and evaluation of awards, Guangdong Ocean University resolutely implement the one-vote veto of teaching. Teachers' morality and style are regarded as the first criterion of teachers' evaluation, and the construction of teachers' morality and style is carried out in every link of talents training.

4) To accelerate the improvement of young teachers' teaching ability, strengthen the tutorial system of young teachers

More "assistant" training can enable young teachers to be competent for the role of teacher. Three-dimensional training should be adopted to improve the teaching level of young teachers. The three-dimensional training is a method that combine academic with non-academic education, intramural and extramural training, online and offline training, routine training and further education abroad. The university will train and bring together a group of young teachers with international vision, innovative ability and development potential in the next few years.

5) To establish incentive mechanism for teaching performance

According to the "four equal importance" of teaching and research work, teaching and scientific research projects, teaching and research results, teaching and scientific research leaders, the university will innovate teaching incentives.

\section{Creating first-class undergraduate majors}

Major is the basic unit of talents training, and the basis of building high-level undergraduate education and training topping talents. To build a first-class undergraduate education, Guangdong Ocean university starts from major construction, are making several efforts.

First, to strengthen top-level design and optimize professional layout. Second, to gather superior resources and build first-class majors. By the demonstration and guidance of these majors, other majors can get improvement, the level of running the whole university has also improved. Third, to perfect the system and strengthen professional evaluation. Professional certification helps to set up the concept of "student-centered, output-oriented and continuous improvement", establish the output-oriented talent training system, upgrade the professional talent training system and create a brand with professional characteristics. Fourthly, to actively fit needs, dynamically adjust structure, establish major adjustment mechanism of survival of the fittest. 


\section{E. Creating a topping training system}

1) A diversified talent training model is necessary for building a first-class undergraduate education

The demand for talents is diverse, and there are differences among students. Only cultivating students individually can meet the society needs. To this end, our university has established a teaching management system to suit for talent training, shifted the focus of teaching management, strengthened the status of colleges, and released the vitality of colleges.

2) A high-level personnel training program is necessary for building a first-class undergraduate education

Comparing Chinese Professional Certification Standards, which reflects the requirements of "Student Center, Goal Orientation and Continuous Improvement", we have conscientiously carried out a new round of personnel training plan revision. The new talent training plan gives more prominence to the innovation orientation, and improves the credit system teaching reform, gives student more choices in major selection, courses selection, class hour setting and so on.

3) A high-level cooperative talent training mechanism is necessary for building a first-class undergraduate education

The university is carrying out pilot projects for the construction of entrepreneurship institute. To establish a "sixin-one" cooperative talent training mechanism, promote indepth cooperation among university, government, research institutes, enterprises and institutions, and collaborate in education.

4) A high level of innovation and entrepreneurship education is necessary for building a first-class undergraduate education

Guangdong Ocean University innovation and entrepreneurship training approved by the community, because of the use of the following measures: ensuring support system, strengthening the innovation and practice of platform construction, building innovation and entrepreneurship education curriculum system, intensifying teaching ability of innovation and entrepreneurship education, cultivating independent thinking and rational judgment ability.

5) A high-quality cultural and sports system is necessary for building a first-class undergraduate education

The university is constantly enriching the forms of campus cultural activities, forming diversified cultural education activities with their own characteristics, and promoting exchanges between students from different cultural backgrounds and subject.

6) High-level international exchanges and cooperation is necessary for building a first-class undergraduate education

The university is exploring a comprehensive training mode with well-known foreign universities to realize the organic connection between our undergraduate education and their postgraduate education, so that more our students can have internationalized learning experience, they are talents with global vision and cross-cultural communication ability.

\section{F. Creating first-class practical teaching}

To achieve the goal of training topping talents, the university is giving more attention to practical education. The methods are as follows: strengthening the top-level design of practical teaching, optimizing the practical teaching system, building an excellent practical teaching team, constructing a first-class platform for practical teaching conditions, promoting the integration of science and education, and straightening out the management system of practical teaching.

\section{G. Constructing a first-class curriculum system}

Course construction is an important support for major construction. The university starts from these aspects: building a scientific curriculum system, establishing a system of chief teachers (responsible persons) and curriculum course managers for major construction, installing a system of curriculum teaching quality evaluation, creating a high level of online open curriculum resources, and setting up a campus of wisdom that can be learned everywhere and at any time.

\section{H. Creating first-class characteristic textbooks.}

The university is encouraging advantageous and distinctive majors to concentrate on compiling a series of textbooks, disseminating the latest research of Guangdong Ocean University and incorporating the results of teaching, treating high-level textbooks and high-level articles equally, and incorporating them into the title evaluation and post appointment system, so as to create conditions for the training of famous teachers and classes, and maximize the dissemination of the university and inheritance of culture.

\section{I. $\quad$ Creating first-class undergraduate classes.}

Classroom teaching is the main part of talent training. The fundamental purpose of teaching reform is to promote class teaching reform. To build every course well, the university is making efforts in the following aspects: renewing teaching notion, innovating teaching methods, expanding course contents, stimulating learning motivation. Creating a smart classroom to meet the needs of self-learning, self-management and self-service, to make teaching information more adequate [12], to promote classroom revolution.

\section{J. Creating first-class education environment}

First, implementing the notion of student-centered. The teacher is the subjectivity of teaching, and student is the subjectivity of learning. The university is setting up a research system of learning, mastering the basic learning data of students, analyzing the data to find out the needs of students in the four-year undergraduate training process. To Improve learning and living environment, the university is making plans, gradually meet learning needs of students. Second, deepening the construction of Institution-building. Thirdly, promoting the standardization of teaching management.

\section{CONCLUSION}

Guangdong Ocean University is fully implementing the spirit of the spirits of Mr. Xi's important speech on inspecting Guangdong, the National Conference on education and the 
National Conference on undergraduate education in the New Era, deepening the educational reform with a high sense of responsibility, and with a spirit of racing against time. Only by implementing the measures mentioned above can Guangdong Ocean University improve the quality of talents training, create a new situation of undergraduate education, and realize a sustainable and healthy development.

\section{ACKNOWLEDGMENT}

Fund Projects: This study was funded by Higher Education Teaching Reform Project of Guangdong China, on Taking Classroom Teaching Reform as a Breakthrough, Exploration and Practice of "Double Creation" Talents Training Mechanism with No. 2018YGJ1-270.

\section{REFERENCES}

[1] Chen Baosheng. Speech at the National Conference on Undergraduate Education in the New Era. China Higher Education Z3:4-10, 2018. (In Chinese)

[2] Xi Jinping. Speech at the Teacher-Student Symposium in Peking University. Socialism Forum 399(05):6-8, 2018.(In Chinese)

[3] Jin Haotian, Chen Peng, Yao Xiaodan, Deng Hui. The fundamental task is to train socialist builders and successors. Guangming Daily, 12 September, 2, 2018. (In Chinese)
[4] Liu Wei, Liu Chuansheng, Chen Jun, Liu Jingtian, Guan Peijun. To study and implement the spirit of General Secretary Xi Jinping's important speeches in Peking University (Written Talks). China Higher Education Research,6:1-5, 2018. (In Chinese)

[5] Wan Yufeng." Universities that do not pay attention to undergraduate education are not qualified ones". China Education Daily, 22 June, 3, 2018. (In Chinese)

[6] Renmin Ribao. Running the education to make people satisfied. Renmin Ribao, 12 September, 1, 2018. (sumitted).

[7] Jiao Xin. Speeding up the Modernization of Education and Writing the Pen of Educational Endeavour. China Education Daily, 15 Septembere,1, 2018. (In Chinese)

[8] Party Building. During his visit to Guangdong, Xi Jinping emphasized holding high the banner of reform and opening-up in the new era and pushing reform and opening-up in depth. Party Building 11:4-6, 2018. (In Chinese)

[9] Wu Yan. First-class universities must have excellent teaching. Guangming Daily, 19 December,13, 2017. (In Chinese)

[10] Liu Wei. Training socialist builders and successors to build world firstclass universities with Chinese characteristics. China Higher Education Z2:4-8, 2018. (In Chinese)

[11] Tang Jingli. Adhering to "Taking Undergraduate Education as the Foundation" and Promoting "Four Returns"--A Review of the National Conference on Undergraduate Education in the New Era. China Higher Education Z2:11-12, 2018. (In Chinese)

[12] Zhang Jin. The Way to Higher Education Classroom in Wisdom Classroom, 2018. (In Chinese) 